\title{
Feeling in Control: The Relationship Between a CEO's Childhood Socio-Economic Status (SES) and Duality
}

\author{
Puya Kahhali \\ University of California, Riverside
}

Duality is the most direct form of control over firm decision-making by CEOs. Yet, while the downstream firm effects of duality have been studied in detail, why certain CEOs are more likely to assume a dual role remains understudied. I propose childhood socio-economic status (SES) as an important driver of a CEO'S propensity to serve as chair of the board. During their upward social transition, CEOs from a low-SES background develop a heightened internal locus of control (i.e., the belief that they themselves are in control of their lives) and consequently become more likely to seek control over their environment. This will be reflected in a higher probability by low-SES CEOs to assume a dual role compared to their non-low SES counterparts. I expect that this relationship will be weakened by factors that act as indirect forms of control over the firm - higher stock price and organizational slack. Drawing on a dataset of Fortune 100 CEOs from 2000 to 2016 I find results in line with the hypothesized relationships.

Keywords: childhood socio-economic status, duality, entrenchment, social mobility, locus of control

\section{INTRODUCTION}

Board of directors are responsible for overseeing that managers uphold the interest of shareholders (Finkelstein \& D'aveni, 1994). Boards are tasked with selecting the CEO, structuring compensation agreements, working closely with the CEO and terminating the CEO's contract when circumstances call for it. In certain cases, however, the CEO may also act as the chair of the board - referred to as duality (Krause \& Semadeni, 2013). Duality is typically justified through the unity of command argument - the closer the board and the CEO work together - the better for shareholders (Boyd, 1995; Donaldson \& Dvais, 1991). The "dark side" of duality is the fact that it is also the most effective and direct form of control over the firm by CEOs (Mallette \& Fowler, 1992, 1995; Shen, 2003).

Whether the CEO serves as the chair of the board has important economic implications for the firm. Prior research has identified duality as an important factor impacting firm performance (Baliga, Moyer, \& Rao, 1996; Finkelstein \& D'aveni, 1994; Iyengar \& Zampelli, 2009), corporate wrongdoing (Beasley, 1996; Cumming, Leung, \& Rui, 2015; Dechow, Sloan, \& Sweeney, 1996) and strategic actions (Krause, Semadeni, \& Cannella, 2014; Quigley \& Hambrick, 2012). Serving as the chair of the board provides the CEO with a decisive influence over the firm's operations and decision-making processes (Boyd, 1995; Fredrickson, Hambrick, \& Baumrin, 1988; Sundaramurthy, Mahoney, \& Mahoney, 1997). Yet, while scholars have extensively studied the implications of duality (Harris \& Helfat, 1998; Rechner \& Dalton, 1991), the individual level factors that drive some CEOs to assume a dual role remain largely unstudied 
(Carpenter, 2011; Hambrick, 2007). I agree with Krause, Semadeni and Cannella (2014) that the literature on duality antecedents remains "sparse" and "underdeveloped" and has yet to reach any "firm conclusions."

An emergent body of interdisciplinary research suggests that childhood socio-economic status (SES) (Cronqvist \& Siegel, 2015; Hayward, Miles, Crimmins, \& Yang, 2000; Miller et al., 2009) and the process of class transitioning (Jackson, Sullivan, Harnish, \& Hodge, 1996; Martin \& Côté, 2019) remain important drivers of behavior into adulthood. A precondition of success for individuals who are born in low SES is the ability to overcome the belief that social progression is made impossible by their environment (Hoxby \& Turner, 2013; Manstead, 2018; Nieuwenhuis, Manstead, \& Easterbrook, 2019). Those who are able to overcome their low SES origins and eventually transition to high SES, do so by developing the belief that they are in charge of their environment and the makers of their own success (Heckhausen, Wrosch, \& Schulz, 2019).

I posit that during their social climb, CEOs from low SES will develop a heightened sense of internal locus of control (belief that they can control the outcomes of their lives through their own actions rather than attribute life outcomes to their external environment). This, I argue will be associated with an increased probability to seek control over one's environment, which at a governance level, will translate into a higher probability of the CEO assuming a dual role. This link will, however, be weakened by indirect forms of control over the firm - stock performance and slack. I explore these relationships within a dataset of Fortune 100 CEOs from 2000 to 2016 and find results consistent with my hypotheses.

There are several important contributions that my research makes. First, my work addresses an important gap in the literature. While scholars have explored in depth the downstream firm effects of duality (Tuggle, Sirmon, Reutzel, \& Bierman, 2010), its antecedents, in particular at the individual level, remain underexplored (Krause et al., 2014). Second, my results contribute to previous work (Chetty, Hendren, Lin, Majerovitz, \& Scuderi, 2016) that has indicated that for American economic elite's origin matters and remains an important factor driving decision-making and behavior. In particular, it extends the CEOfocused literature (Kish-Gephart \& Campbell, 2015; Martin, Côté, \& Woodruff, 2016; Kahhali, 2021a; Kahhali, 2021b; Kahhali, 2022a; Kahhali, 2022b; Kahhali, 2022c) that has identified childhood social class as an important factor behind firm level outcomes. Second, my work makes an original contribution to the literature on social mobility (Martin \& Côté, 2019). My results indicate that in their transition from low social class to elite, social transitioners will develop a heightened internal locus of control, which will be reflected in a greater propensity to seek control in executive positions.

\section{THEORETICAL BACKGROUND AND HYPOTHESES}

\section{Low SES, Locus of Control and Social Transitioning}

Locus of control is the "most distinctly core property of human agency" (Bandura, 2006: 165). It is fundamental to individual identity, perception of social structures and action (Bandura, 2006; Rotter, 1966) . Individuals with an external locus of control succumb to the dominance of their environments while those with an internal locus of control believe that they can control their environments and seek to do so (Phares, 1976). Individuals with internal locus of control, however, exhibit higher self-esteem levels (Judge, Bono, Erez, \& Thoresen, 2002) and an increased probability to seek control (Reitz \& Jewel, 1979).

Prior research has linked low SES with external locus of control (Battle \& Rotter, 1963) and has referred to this relation as a "hidden injury" of social class (Sennet \& Cobb, 1972). Individuals from disadvantaged backgrounds are more likely to attribute personal and economic outcomes to external circumstances (Battle \& Rotter, 1963; Findley \& Cooper, 1983). Conditioned by the limited sense of control, low SES individuals are less likely to pursue actions that would challenge the presupposition of externally dictated outcomes. For instance, they are less likely to apply for elite universities (Hoxby \& Turner, 2013; Nieuwenhuis, Manstead, \& Easterbrook, 2019), seek prestigious jobs (Manstead, 2018) or start a business (Brockhaus, 1975). Failure to engage in any of these "circuit breaking" actions further reaffirm the limits of their control. In this sense, then, the external locus becomes a "self-fulfilling prophecy," in which failure to take corrective actions ensures the realization of pre-existent expectations of lack of control (Phares, 1965). 
Those who do break this vicious cycle and succeed in transitioning from low to high SES - must and are able to overcome the limited sense of control (Heckhausen, Wrosch, \& Schulz, 2019). The ability to get over the substantial barriers imposed by their socio-economic position allows low-to-elite social climbers to challenge external locus of control perspectives (e.g., action futility) and develop an internal locus of control (Bowman \& Howard, 1985). Research indicates that experiences of becoming successful despite the odds set by their background makes successful individuals from low SES to develop a heightened sense of self-esteem and confidence (Duckworth \& Schoon, 2012).

I posit that in their successful transition from the peripheries of social order to its top, CEOs with low SES roots to develop a heightened sense of internal locus of control compared to those with middle-andhigh SES origins. While both low-SES and non-low-SES CEOs, by the nature of their positions, would demonstrate an internal locus of control, there will be, I argue, a difference in degree. Unlike those born in low SES, the success of those born in middle and high SES is in many ways a byproduct of a system that is set up to favor them (Belmi, Neale, Reiff, \& Ulfe, 2019). Although both those from the middle as well as those from high SES could contend a trying path towards their success, none can claim the confidence of doing so in the face of an environment which puts them at a deep disadvantage (Belmi et al., 2019). Considering the awareness of the profound socio-economic barriers they had to overcome and the demands of the social climb from the bottom of the social order to its zenith - CEOs from low SES backgrounds will develop, I argue, a more pronounced sense of internal control compared to those born in middle or high SES.

\section{Duality and Firm Control}

Duality provides a CEO with the most direct path to control over the firm (Mallette \& Fowler, 1992, 1995; Shen, 2003). By serving in a dual role the CEO exerts direct influence over the firm and its decisionmaking processes (Deutsch, Keil, \& Laamanen, 2007; Eisenhardt, 1989; Judge \& Miller, 1991). As noted by Hambrick and Finkelstein "[D]uality increases chief executive discretion by providing a broader power base and locus of control, and by weakening the relative power of other interest groups" (Hambrick \& Finkelstein, 1987: 379). While duality provides a CEO with the most direct mechanism for control over the firm, it also makes the CEO the focal point for blame should things go wrong. Prior work has suggested that CEOs in dual positions are more likely to be replaced as a result of underperformance (Harrison, Torres, \& Kukalis,1988). Assuming duality, hence, would require a CEO to be highly confident in one's abilities (Rijsenbilt \& Commandeur, 2013).

Considering that individuals who progress from low SES to the socioeconomic elite develop a heightened sense of internal locus of control, I posit that they are more likely to assume a dual governance role than their non-low SES counterparts. In formal terms:

Hypothesis 1: CEOs from a low SES background are more likely to be associated with duality.

\section{Indirect Forms of Control}

Although a CEO can exert great influence over the firm through duality, the same outcome can be achieved indirectly through excellent performance. If the firm is currently performing well and facing excellent performance outlooks, the CEO is more likely to be granted a greater degree of influence (Daily \& Johnson, 1997). In this regard, then, current and future performance outlooks act as a de facto substitute for influence over the firm's decision-making. I posit that the association between a CEOs SES background and duality will be weakened by factors that would provide an indirect control over the firm such as current performance and a favorable outlook on a firm's prospects - specifically current stock price and organizational slack.

Stock Price

A firms' stock price is the most commonly used indicator of a firm's current performance and its future prospects (Huselid, Jackson, \& Schuler, 1997). Its use can be attributed to its wide availability and ease of interpretation (Beatty \& Zajac, 1987). Relying on market forces to uncover inefficiencies, audiences can 
quickly gauge a firm's financial condition and future outlook simply by tracking the performance of its publicly traded stock. Positive (negative) current and future expectations will drive the stock price up (down) (Dechow, Hutton, \& Sloan, 2000). While often driven by subjective considerations, a high stock evaluation has real impacts on the firm - by making it easier to access financing (Bharath, Sunder, \& Sunder, 2008), attract and retain talent (Kaplan, 1993) and manage audiences' impression (good press) (Hammond \& Slocum, 1996). Given its saliency and objective impacts on the firm - a stock price is closely watched by shareholders and board members alike (Puffer \& Weintrop, 1991) and a strong stock performance is associated with increased CEO control over the firm (Pearce \& Zahra, 1991).

Considering that a high stock price provides an indirect form of control over firm decision-making, I posit that it will weaken the association between a CEO's low childhood SES and duality. More precisely, I hypothesize:

Hypothesis 2: The association between CEOs' low SES background and duality is weakened by high stock prices.

Slack

Research often associates slack with positive firm financial health (Bourgeois, 1981). Firms with consistently good performance will over time accumulate an increasing level of resource slack (Cyert \& March, 1963). Higher levels of slack, in turn, offer firms with an important advantage (George, 2005), by providing the necessary resources to innovate (Thompson, 1996) and the room to pursue risky high-payoff strategies (Mohr, 1969). From the perspective of the CEO - slack represents both a confirmation of one's excellence (Singh, 1986) and an opportunity to further indirectly control through increased levels of discretion (Finkelstein \& Boyd, 1998).

Considering that high levels of slack provide an indirect form of control over firm decision-making, I posit that it will weaken the association between a CEO's childhood SES and duality. More precisely, I hypothesize:

Hypothesis 3: The association between CEOs' low SES background and duality is weakened by high levels of slack.

\section{DATA AND METHODS}

I examine the association between a CEOs low SES background and the probability of assuming a dual role and the moderating effects of stock price and organizational slack within the context of firms that appeared at least once in Fortune 100 from 2000 to 2016. Over that span a total of 164 firms and 452 unique CEOs appeared in the ranking.

Our motivation for focusing on this specific set of firms and time period is three-fold. First, Fortune 100 covers the largest American firms. These firms are highly visible and servings as the CEO of one of them comes with significant levels of pressure. Second, focusing on the Fortune 100 ranking ensured that firms in my sample faced a relatively common set of behavioral expectations both in terms of hiring as well as in terms of governance practices. Finally, examining a highly tracked set of firms during a recent time period provided assurances that I would be able to locate CEO and firm level data.

\section{Dependent Variable}

CEO duality. My dependent variable is duality. Data were obtained from Institutional Shareholder Services (ISS). In line with prior research (Iyengar \& Zampelli, 2009) the variable was coded as a 1 if in a given year the CEO also served as the chair of the board and 0 otherwise.

\section{Independent Variables and Moderators}

CEO social class upbringing. A CEO's SES during one's development years represents my main independent variable. Biographical profiles of each CEO were created based on background data collected 
from publicly available sources, Factiva and BoardEx databases. Each profile was reviewed and coded by three coders, working independently and naive to the study's hypotheses. A CEO was coded as originating from low SES if at least two of the three coders coded one's profile as such. The Fleiss' Kappa (Fleiss, Levin, \& Paik, 2013) for inter-coder reliability was 0.76 . The results of the coding revealed that $13 \%$ of the CEOs in my sample grew up in low SES.

Stock Price

Our first moderating variable is closing stock price at the end of the fiscal year. Data were obtained from Compustat. To alleviate skewness and outlier concerns following accepted practices in the field I logtransformed the data.

Slack

Our second moderating variable is slack. Following (George, 2005) I conceptualize slack as current year cash reserves held by the firm. Data were obtained from Compustat. To alleviate skewness and outlier concerns following accepted practices in the field I log-transformed the data.

\section{Control Variables}

To account for other factors' impacts on the probability of a CEO assuming a dual role, my models incorporate several individual and firm level controls.

\section{CEO Level Controls}

Prior research has identified education (MacCrimmon \& Wehrung, 1990; Thomas, Litschert, \& Ramaswamy, 1991; Wiersema \& Bantel, 1992) and in particular elite education (Finkelstein, 1992) as an important influence over one's career path as well as decision-making as CEO. To control for the effects of a CEO's education my models include a dummy variable that reflects whether the CEO holds a degree from an elite educational institution (Finkelstein, 1992). Data were obtained through publicly available source and BoardEx. In addition to education, tenure has previously identified as a significant factor in determining CEO power dynamics (Shen \& Cannella, 2002). To account for this possibility my models also control for CEO tenure. Finally, prior work has indicated that childhood traumatic events can condition a CEO's behavior during one's tenure (Bernile, Bhagwat, \& Rau, 2017). To capture this possibility, I include a dummy variable that captures whether a CEO has experienced an economic recession before the age of 21. Finally, I include a dummy variable to account for CEO's gender.

\section{Firm Level Controls}

Following prior work, I use total assets (Finkelstein \& D'aveni, 1994), total debt (Berger, Ofek, \& Yermack, 1997) and total market value (Fama \& French, 1992) to control for firm level factors. I log transform all three. I also control for a firm's current performance by including return on assets (Daily \& Dalton, 1994). To ensure that my results are not driven by outliers I winsorize all four at $1 \%$ and $99 \%$ levels. All these data points were obtained from Compustat. Finally, my models include year fixed effects.

\section{Data Analysis}

Given the characteristics of my dependent variable, for my analyses I employ panel logistic regression. The Hausman (1978) test for systematic differences between fixed and random effects models was significant, hence I opt for a firm-level fixed effects specification. The Wald test for groupwise heteroskedasticity was also significant (Baum, 2001) and consequently for my models I use the robust standard error specification with errors clustered at the firm level.

\section{RESULTS}

Table 1 provides firm-level descriptive statistics for the sample. The model results are reported in Table 2. Model 1 includes controls only. In this model tenure is positively associated with duality, while R\&D 
and the CEO experiencing a recession during development years have a negative association. Hypothesis 1 predicted that, when compared to CEOs who grew in other social classes, CEOs from low SES backgrounds are more likely to seek a dual governance role. Models 2 through 4 provide support for hypothesis 1 - as hypothesized, CEOs who grew up in low SES are three times more likely to assume a dual governance role. Hypothesis 2 proposed that stock price weakens the relationship between a CEO's low SES background and duality. Models 3 and 4 provide confirmatory findings for this moderating relationship - higher stock prices weaken the relationship between a CEO's low SES background and the probability of the CEO to assume the position of the chair of the board. Finally, hypothesis 3 posited that organizational slack weakens the relationship between a CEO's low SES background and duality. Models 4 and 5 offer supporting evidence for this hypothesized effect - higher firm slack weakens the relationship between a CEO's low SES background and duality.

TABLE 1

DESCRIPTIVE STATISTICS

\begin{tabular}{llllll}
\hline Variable & N & Min & Max & Mean & SD \\
\hline Tenure (years) & 2499 & 1.00 & 50.00 & 6.75 & 4.52 \\
CEO Share Ownership (\%) & 1216 & 0.00 & 33.5 & 1.53 & 6.20 \\
ROA (ratio) & 2492 & -1.09 & 0.90 & 0.05 & 0.08 \\
Stock Price (\$) & 2426 & 0.03 & $141,600.00$ & 433.94 & $6,078.74$ \\
Cash Reserves (\$ millions) & 2453 & 0.06 & $159,353.00$ & $5,498.25$ & $11,753.94$ \\
Total Assets (\$ millions) & 2492 & 10.46 & $3,287,968.00$ & $145,305.40$ & $356,237.90$ \\
Total Debt (\$ millions) & 2491 & 0.00 & $3,226,737.00$ & $36,571.35$ & $196,558.50$ \\
Total Market Value (\$ millions) & 2214 & 1.45 & $626,550.40$ & $57,151.70$ & $76,699.89$ \\
\hline
\end{tabular}

TABLE 2

DUALITY BY SES, STOCK PRICE AND SLACK

\begin{tabular}{|c|c|c|c|c|c|}
\hline & M1 & M2 & M3 & M4 & M5 \\
\hline Low SES & & $\begin{array}{l}1.173^{*} \\
(0.530)\end{array}$ & $\begin{array}{l}3.617 * * \\
(1.273)\end{array}$ & $\begin{array}{l}6.070 * * \\
(2.079)\end{array}$ & $\begin{array}{l}\text { 7.184*** } \\
(2.077)\end{array}$ \\
\hline Low SES x Stock Price & & & $\begin{array}{l}-0.682 * \\
(0.298)\end{array}$ & & $\begin{array}{l}-0.521 \dagger \\
(0.288)\end{array}$ \\
\hline Low SES x Slack & & & & $\begin{array}{l}-0.654 * \\
(0.282)\end{array}$ & $\begin{array}{l}-0.555 * \\
(0.273)\end{array}$ \\
\hline Stock Price $(\log )$ & & & $\begin{array}{l}-0.0171 \\
(0.420)\end{array}$ & & $\begin{array}{l}0.0868 \\
(0.410)\end{array}$ \\
\hline Slack (log) & & & & $\begin{array}{l}0.0328 \\
(0.224)\end{array}$ & $\begin{array}{l}0.0204 \\
(0.223)\end{array}$ \\
\hline
\end{tabular}




\begin{tabular}{|c|c|c|c|c|c|}
\hline & M1 & M2 & M3 & M4 & M5 \\
\hline \multirow{2}{*}{ Tenure } & $0.350 * * *$ & $0.359 * * *$ & $0.358 * * *$ & $0.360 * * *$ & $0.358 * * *$ \\
\hline & $(0.0626)$ & $(0.0637)$ & $(0.0637)$ & $(0.0654)$ & $(0.0652)$ \\
\hline \multirow[t]{2}{*}{ Elite Education } & 0.0786 & 0.154 & 0.149 & 0.0286 & 0.0366 \\
\hline & $(0.479)$ & $(0.479)$ & $(0.481)$ & $(0.497)$ & $(0.495)$ \\
\hline \multirow{2}{*}{ Experienced Recession (before 21) } & $-2.845^{*}$ & $-2.847 *$ & $-3.017 *$ & $-2.886^{*}$ & $-2.990 *$ \\
\hline & $(1.281)$ & $(1.248)$ & $(1.259)$ & $(1.297)$ & $(1.306)$ \\
\hline \multirow[t]{2}{*}{ Female } & 0.0191 & -0.342 & -0.224 & -0.287 & -0.205 \\
\hline & $(1.110)$ & $(1.174)$ & $(1.164)$ & $(1.305)$ & $(1.300)$ \\
\hline \multirow[t]{2}{*}{ Total Assests (log) } & -0.169 & -0.187 & -0.277 & -0.0437 & -0.0854 \\
\hline & $(0.254)$ & $(0.258)$ & $(0.286)$ & $(0.275)$ & $(0.290)$ \\
\hline \multirow{2}{*}{ ROA } & 1.071 & 1.094 & 1.121 & 0.995 & 0.899 \\
\hline & (1.009) & (1.116) & (1.132) & $(1.251)$ & $(1.235)$ \\
\hline \multirow{2}{*}{ Total Deb $(\log )$} & 0.171 & 0.155 & 0.173 & 0.177 & 0.190 \\
\hline & $(0.137)$ & $(0.138)$ & $(0.137)$ & $(0.138)$ & $(0.138)$ \\
\hline \multirow[t]{2}{*}{ Total Market Value (log) } & -0.153 & -0.207 & -0.109 & -0.218 & -0.201 \\
\hline & $(0.160)$ & $(0.164)$ & $(0.361)$ & $(0.179)$ & $(0.361)$ \\
\hline Year Dummies & Yes & Yes & Yes & Yes & Yes \\
\hline $\mathrm{N}$ & 1,559 & 1,559 & 1,559 & 1,534 & 1,534 \\
\hline R-square & 0.2589 & 0.2678 & 0.2724 & 0.2814 & 0.2837 \\
\hline \multicolumn{6}{|l|}{ Standard errors in parentheses } \\
\hline$\dagger \mathrm{p}<0.10, * \mathrm{p}<0.05, * * \mathrm{p}<0.01, * * * \mathrm{p}<0.001$ & & & & & \\
\hline
\end{tabular}

Figures 1 and 2 provide visual representations of the moderating effects of stock price and slack. Based on Model 5, the expected probability for a CEO with low-SES background to entrench decreases from 87\% to $40 \%$ for high stock valuations. For high levels of slack compared to low levels of slack this probability drops from $98 \%$ to $32 \%$. 
FIGURE 1

EFFECTS OF STOCK PRICE ON THE PROBABILITY OF ENTRENCHMENT BY CEOS FROM LOW SES BACKGROUNDS

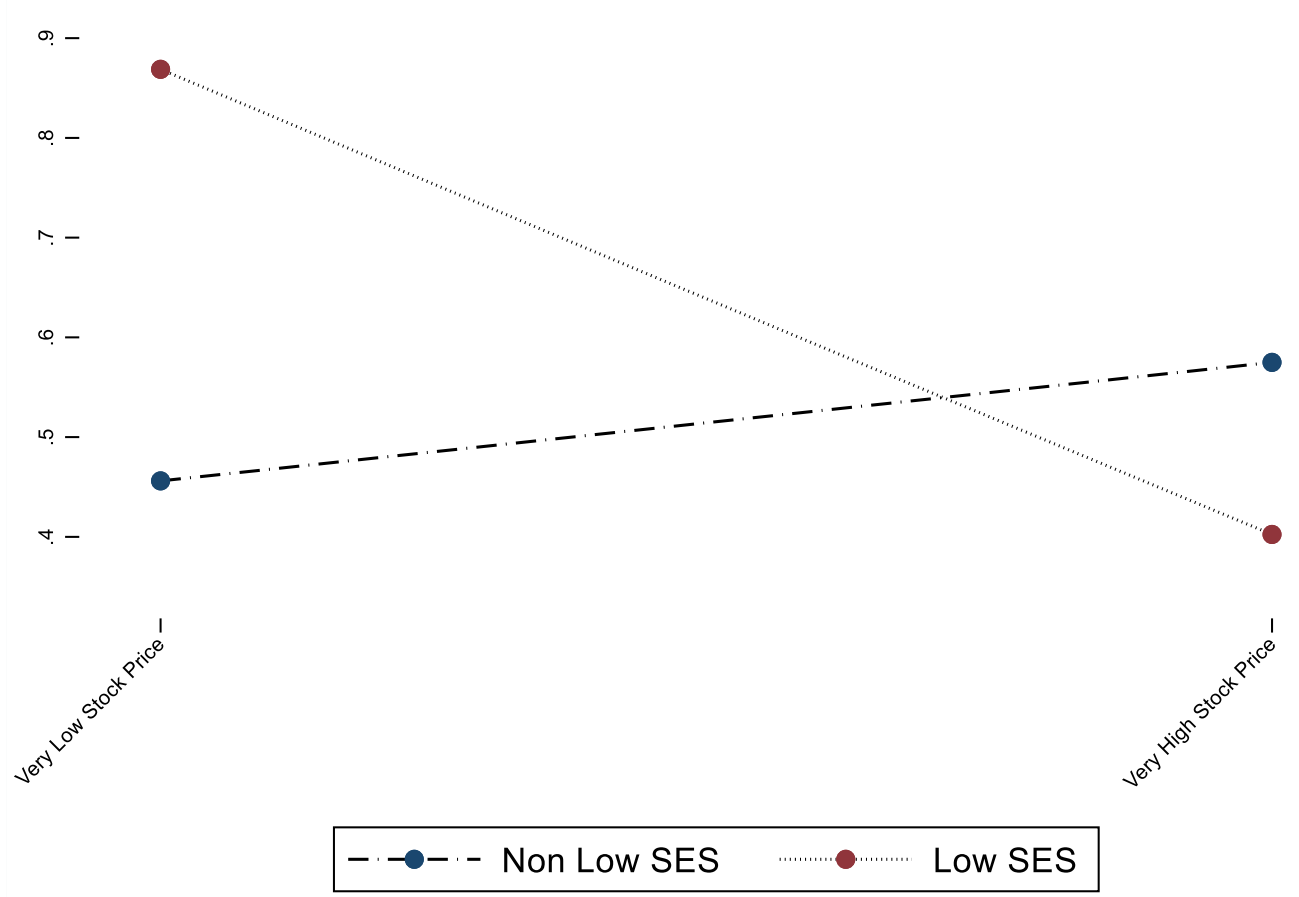

FIGURE 2

EFFECTS OF SLACK ON THE PROBABILITY OF ENTRENCHMENT BY CEOS FROM LOW SES BACKGROUNDS

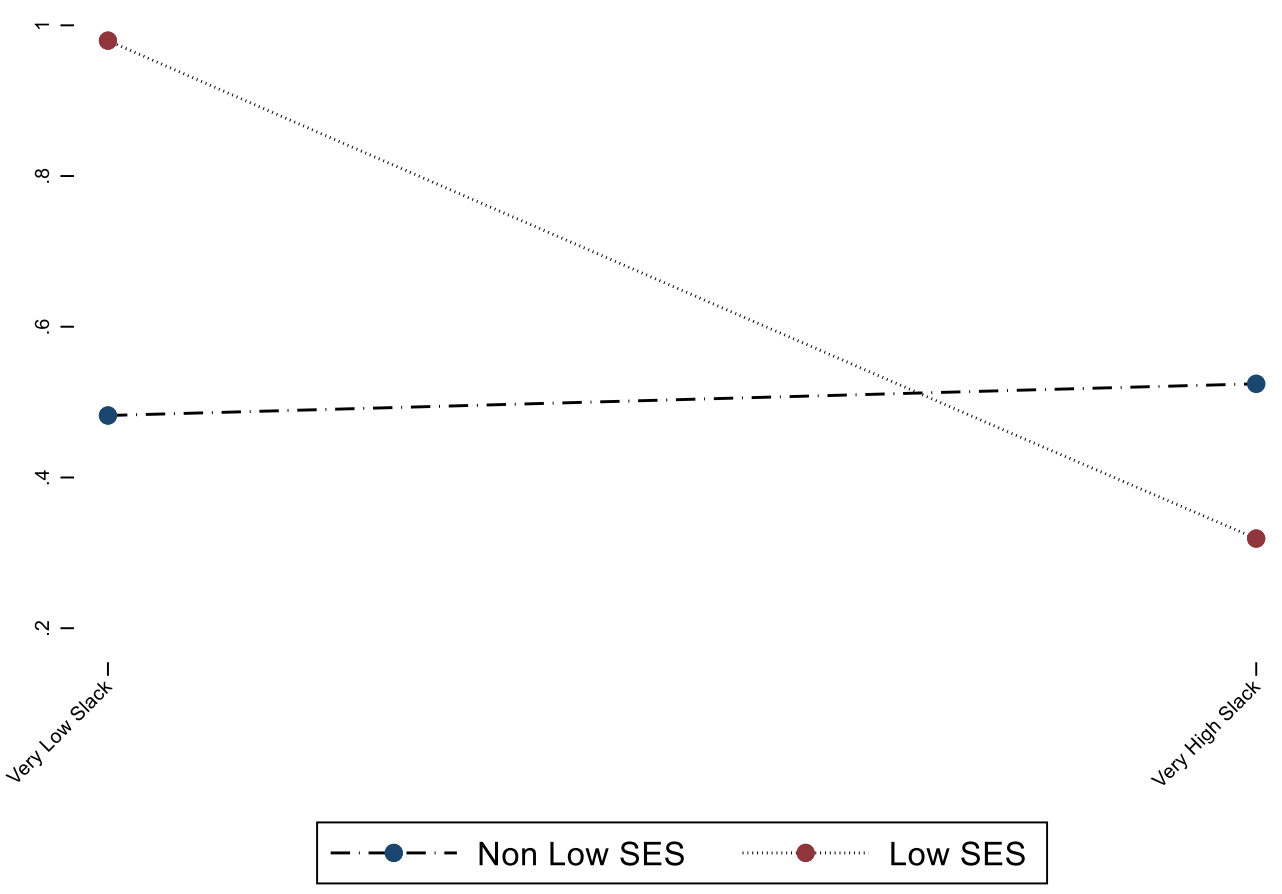




\section{Robustness Checks}

To confirm the robustness of my results and address possible limitations I conducted several additional analyses and robustness tests.

All SES groups analyses. One possible theoretical challenge to my study might be associated with the fact that the results are driven mainly by single sub-group relationship (low vs. middle or low vs. high, rather than both). To examine this possible limitation, I replicate my analyses by breaking down the nonlow SES subgroup into middle and high. The result of these additional analyses (Table 3) show that my results are not a byproduct of differences between a single subgroup relationship - CEOs from low SES are more likely than those from middle as well as those from high SES to seek entrenchment.

TABLE 3

DUALITY BY SES (LOW, MIDDLE AND HIGH), STOCK PRICE AND SLACK

\begin{tabular}{|c|c|c|c|c|}
\hline & M1 & $M 2$ & M3 & M4 \\
\hline Middle SES & $\begin{array}{l}-1.166^{*} \\
(0.553)\end{array}$ & $\begin{array}{l}-4.517 * * \\
(1.490)\end{array}$ & $\begin{array}{l}-6.402 * * \\
(2.118)\end{array}$ & $\begin{array}{l}-8.088 * * * \\
(2.192)\end{array}$ \\
\hline High SES & $\begin{array}{l}-1.186 \\
(0.617)\end{array}$ & $\begin{array}{l}-2.761 \dagger \\
(1.419)\end{array}$ & $\begin{array}{l}-5.490^{*} \\
(2.301)\end{array}$ & $\begin{array}{l}-5.941 * \\
(2.423)\end{array}$ \\
\hline Middle SES x Stock Price & & $\begin{array}{l}0.936 * * \\
(0.344)\end{array}$ & & $\begin{array}{l}0.737 * \\
(0.358)\end{array}$ \\
\hline High SES x Stock Price & & $\begin{array}{l}0.422 \\
(0.374)\end{array}$ & & $\begin{array}{l}0.291 \\
(0.356)\end{array}$ \\
\hline Middle SES x Slack & & & $\begin{array}{l}0.693 * \\
(0.292)\end{array}$ & $\begin{array}{l}0.568 \\
(0.291)\end{array}$ \\
\hline High SES x Slack & & & $\begin{array}{l}0.581 \dagger \\
(0.312)\end{array}$ & $\begin{array}{l}0.496 \dagger \\
(0.302)\end{array}$ \\
\hline Stock Price & & $\begin{array}{l}-0.690 \\
(0.471)\end{array}$ & & $\begin{array}{l}-0.430 \dagger \\
(0.471)\end{array}$ \\
\hline Slack & & & $\begin{array}{l}-0.603 \dagger \\
(0.329)\end{array}$ & $\begin{array}{l}-0.505 \\
(0.313)\end{array}$ \\
\hline Tenure & $\begin{array}{l}0.359 * * * \\
(0.0638)\end{array}$ & $\begin{array}{l}0.366 * * * \\
(0.0646)\end{array}$ & $\begin{array}{l}0.362 * * * \\
(0.0656)\end{array}$ & $\begin{array}{l}0.366^{* * * *} \\
(0.0665)\end{array}$ \\
\hline Elite Education & $\begin{array}{l}0.158 \\
(0.490)\end{array}$ & $\begin{array}{l}0.0871 \\
(0.494)\end{array}$ & $\begin{array}{l}0.0190 \\
(0.512)\end{array}$ & $\begin{array}{l}-0.0260 \\
(0.509)\end{array}$ \\
\hline Experienced Recession (before 21) & $\begin{array}{l}-2.853 * \\
(1.284)\end{array}$ & $\begin{array}{l}-3.132 * \\
(1.348)\end{array}$ & $\begin{array}{l}-2.870^{*} \\
(1.312)\end{array}$ & $\begin{array}{l}-3.053 * \\
(1.338)\end{array}$ \\
\hline Female & $\begin{array}{l}-0.343 \\
(1.173)\end{array}$ & $\begin{array}{l}-0.109 \\
(1.110)\end{array}$ & $\begin{array}{l}-0.298 \\
(1.294)\end{array}$ & $\begin{array}{l}-0.125 \\
(1.226)\end{array}$ \\
\hline Total Assets $(\log )$ & $\begin{array}{l}-0.186 \\
(0.260)\end{array}$ & $\begin{array}{l}-0.274 \\
(0.281)\end{array}$ & $\begin{array}{l}-0.0568 \\
(0.283)\end{array}$ & $\begin{array}{l}-0.107 \\
(0.299)\end{array}$ \\
\hline ROA & $\begin{array}{l}1.095 \\
(1.112)\end{array}$ & $\begin{array}{l}1.228 \\
(1.215)\end{array}$ & $\begin{array}{l}0.991 \\
(1.236)\end{array}$ & $\begin{array}{l}1.032 \\
(1.322)\end{array}$ \\
\hline Total Debt & $\begin{array}{l}0.156 \\
(0.136)\end{array}$ & $\begin{array}{l}0.181 \\
(0.133)\end{array}$ & $\begin{array}{l}0.180 \\
(0.138)\end{array}$ & $\begin{array}{l}0.199 \\
(0.135)\end{array}$ \\
\hline Total Market Value & -0.208 & -0.114 & -0.219 & -0.203 \\
\hline
\end{tabular}




\begin{tabular}{lllll}
\hline Year Dummies & Yes & Yes & Yes & Yes \\
\hline & & & & \\
$\mathrm{N}$ & 1,559 & 1,559 & 1,534 & 1,534 \\
R-square & 0.2678 & 0.2762 & 0.2821 & 0.2871 \\
\hline
\end{tabular}

Robust standard errors in parentheses

$\dagger \mathrm{p}<0.10, * \mathrm{p}<0.05, * * \mathrm{p}<0.01, * * * \mathrm{p}<0.001$

Alternative dependent variable analyses. Although duality is the most direct mechanism for a CEO to achieve control, a similar effect can be obtained indirectly through share ownership (O'Connor, Priem, Coombs, \& Gilley, 2006). Due to 0-truncated distribution of my dependent variable for my estimation I employ panel Poisson regression with fixed effects specification (Hölldobler \& Wilson, 1977). Data on CEO share ownership were obtained from ExecuComp database. Within the context of smaller sample, I was able to replicate my main finding (Table 4).

TABLE 4

PERCENTAGE OF FIRM SHARE OWNERSHIP BY SES, STOCK PRICE AND SLACK

\begin{tabular}{|c|c|c|c|c|c|}
\hline & $M 1$ & $M 2$ & M3 & M4 & $M 5$ \\
\hline Low SES & & $\begin{array}{l}1.374 \\
(0.986)\end{array}$ & $\begin{array}{l}3.940^{* *} \\
(1.281)\end{array}$ & $\begin{array}{l}4.368^{* * *} \\
(1.611)\end{array}$ & $\begin{array}{l}3.710^{* *} \\
(1.240)\end{array}$ \\
\hline Low SES x Stock Price & & & $\begin{array}{l}-0.864 * * * \\
(0.251)\end{array}$ & & $\begin{array}{l}-0.944 * * \\
(0.349)\end{array}$ \\
\hline Low SES x Slack & & & & $\begin{array}{l}-0.459^{*} \\
(0.185)\end{array}$ & $\begin{array}{l}0.0664 \\
(0.234)\end{array}$ \\
\hline Stock Price (log) & & & $\begin{array}{l}0.0415 \dagger \\
(0.0243)\end{array}$ & & $\begin{array}{l}0.0487 \dagger \\
(0.0252)\end{array}$ \\
\hline Slack $(\log )$ & & & & $\begin{array}{l}-0.124 \\
(0.0989)\end{array}$ & $\begin{array}{l}-0.153 \\
(0.0968)\end{array}$ \\
\hline Tenure & $\begin{array}{l}0.0866 * * \\
(0.0263)\end{array}$ & $\begin{array}{l}0.0655^{* *} \\
(0.0235)\end{array}$ & $\begin{array}{l}0.0712 * * * \\
(0.0207)\end{array}$ & $\begin{array}{l}0.0762 * * * \\
(0.0227)\end{array}$ & $\begin{array}{l}0.0719 * * \\
(0.0236)\end{array}$ \\
\hline Elite Education & $\begin{array}{l}0.647 \\
(0.523)\end{array}$ & $\begin{array}{l}0.592 \\
(0.500)\end{array}$ & $\begin{array}{l}0.585 \\
(0.495)\end{array}$ & $\begin{array}{l}0.564 \\
(0.469)\end{array}$ & $\begin{array}{l}0.505 \\
(0.452)\end{array}$ \\
\hline Experience Recession (before 21) & $\begin{array}{l}-0.462 \\
(0.606)\end{array}$ & $\begin{array}{l}-0.690 \\
(0.601)\end{array}$ & $\begin{array}{l}-0.740 \\
(0.603)\end{array}$ & $\begin{array}{l}-0.647 \\
(0.583)\end{array}$ & $\begin{array}{l}-0.747 \\
(0.609)\end{array}$ \\
\hline Female & $\begin{array}{l}-0.0190 \\
(0.574)\end{array}$ & $\begin{array}{l}-0.305 \\
(0.639)\end{array}$ & $\begin{array}{l}0.0515 \\
(0.446)\end{array}$ & $\begin{array}{l}-0.744 \\
(0.533)\end{array}$ & $\begin{array}{l}-0.167 \\
(0.463)\end{array}$ \\
\hline Total Assets (log) & $\begin{array}{l}-0.219 \\
(0.219)\end{array}$ & $\begin{array}{l}-0.162 \\
(0.223)\end{array}$ & $\begin{array}{l}-0.181 \\
(0.205)\end{array}$ & $\begin{array}{l}-0.0621 \\
(0.224)\end{array}$ & $\begin{array}{l}-0.0708 \\
(0.206)\end{array}$ \\
\hline ROA & $\begin{array}{l}-0.608 \\
(1.085)\end{array}$ & $\begin{array}{l}-0.469 \\
(0.993)\end{array}$ & $\begin{array}{l}-0.142 \\
(0.957)\end{array}$ & $\begin{array}{l}-0.395 \\
(0.914)\end{array}$ & $\begin{array}{l}-0.296 \\
(0.884)\end{array}$ \\
\hline
\end{tabular}




\begin{tabular}{llllll}
\hline Total Debt (log) & 0.135 & 0.132 & 0.132 & 0.127 & 0.123 \\
& $(0.0878)$ & $(0.0861)$ & $(0.0898)$ & $(0.0860)$ & $(0.0880)$ \\
Total Market Value (log) & -0.0974 & -0.163 & -0.221 & -0.173 & -0.211 \\
& $(0.183)$ & $(0.168)$ & $(0.161)$ & $(0.146)$ & $(0.145)$ \\
Year Dummies & Yes & Yes & Yes & Yes & Yes \\
N & & & & & \\
Log Likelihood & 952 & 952 & 952 & 928 & 928 \\
\hline & -599.92 & -592.64 & -583.013 & -573.52 & -567.99 \\
\hline
\end{tabular}

Robust standard errors in parentheses

$\dagger \mathrm{p}<0.10, * \mathrm{p}<0.05, * * \mathrm{p}<0.01, * * * \mathrm{p}<0.001$

Alternative dependent variable - null effect hypothesis. A potential alternative interpretation of my results could be that CEOs with low-SES origins seek duality mainly driven by "fear of falling" rather by an underlying sense of internal locus of control. To exclude "fear of falling" driving my results I examined my models with golden parachutes as an alternative dependent variable. A golden parachute is a substantial compensation package that CEOs (and other executives) receive in the case of a takeover of merger (Hill \& Phan, 1991). If the mechanism is couched "fear of falling" rather than locus of control, I should find a positive association between a CEO's low-SES background and the presence of golden parachutes policies. My additional analyses with golden parachutes as an alternative dependent variable provide no support for such an association - I fail to identify a statistically significant relationship between a CEO's SES origin and a firm's probability of adopting golden parachutes. I do, however, identify a statistically significant relationship between whether a CEO experienced an economic recession before the age of 21 and the probability of the firm enacting golden parachute packages. Firms run by CEOs who were 21 years old or younger before 1985 are more likely to enact golden parachutes to compensate executives in the case of a potential "fall."

Alternative moderator analyses. To further examine the association mechanism between a CEO's low SES background I employ an alternative moderator. I use book value per share. The former is an appropriate alternative moderator for my case because similar to stock price and to slack it is an easily interpretable and highly tracked measure that it is associated with a firm's current performance and future outlook (Chakravarthy, 1986). Prior research has indicated that CEO control over the firm is positively associated with increases in book value per share (Ryan \& Wiggins, 2004). Using this alternative moderator specification, I am able to replicate my main finding.

Robustness tests. Endogeneity by selection raises an important challenge to my findings. It is possible that Fortune 100 with certain stock and slack characteristics are more likely to employ CEOs who grew up in low SES. To exclude this as a possible driver for my results I rerun my main model while instrumenting CEO low SES as a function of stock price and slack. The Wald test for endogeneity is insignificant, hence, I can exclude endogeneity through selection as a possible driver for my results (Wooldridge, 2010). Another important endogeneity related concern is the one associated with omitted variable bias. To test for the latter, I employed an impact threshold of a confounding variable (ITCV) test (Xu et al. 2019). The results of the ITCV test indicated that the omitted variable would have to be correlated at 0.19 with both dependent and independent variables ( $41 \%$ of the estimates would have to be due to bias) in order to invalidate my inference. Given the fixed effects specifications of my models, 11 covariates and year dummies it is unlikely that an omitted variable would invalidate my results.

\section{DISCUSSION}

Management literature regularly links duality with important downstream impacts. Yet, while the effects of duality have been studied in detail (Boyd, 1995; Fredrickson et al., 1988; Sundaramurthy et al., 1997), what drives CEOs to assume duality remains largely unexplored (Krause et al., 2014). My work 
identifies a CEO's childhood SES as an important factor behind the propensity of a CEO to assume a dual role. In the process of transition, individuals born in low SES will develop a heightened internal locus of control, which will translate into a higher probability of entrenchment while in executive positions. In line with prior work (Kish-Gephart \& Campbell, 2015; Martin et al., 2016; Kahhali, 2021a; Kahhali, 2021b) my results indicate that childhood experiences and the process of social transition leave lasting imprints which continue to shape CEOs' behavior and decision-making. In this sense, then, the explanation for a CEO's current governance preferences might be enclosed in the past rather than in objective strategic factors.

Although my empirical findings are robust and grounded in a sound theoretical framework, my study is not without limitations. By design the main limitation of my study is the inability to directly measure CEOs' locus of control, as such a task would be to a certain extent unrealistic. While I was unable to measure locus of control directly, my moderation and alternative model specification analyses provide us with a sense of confidence that differences in locus of control is indeed the mechanism at play. A second important limitation associated with my study is the fact that I was not able to trace social transitioning paths. While regardless of paths, individuals climbing the social ladder from low SES all the way to the top have to overcome the constraints of external locus of control - the nature of their route to the top is also bound to be impactful. The methodological limits imposed by my data and study design did not allow us to pursue these in more detail and they remain important research opportunities that warrant future attention.

\section{CONCLUSION}

CEOs differ in terms of their social origins and the paths they take into the elite. Some don't have far to go while others have to make an arduous climb (Kish-Gephart \& Campbell, 2015). The latter must not only overcome the socio-economic disadvantages of their social origin, but also the psychological limits imposed by perspective of external locus of control that surrounds them while growing up. My results point to the fact that for CEOs from low SES, the proven success of defying the disadvantages of their birth class and completing the social climb will result in an increased propensity to seek a dual role - evidencing the long-lasting imprint of social origin. In this sense, then, part of the answer to the question why some CEOs will push for duality while others would be less concerned with it - will lie in the past.

\section{REFERENCES}

Allison, P.D., \& Waterman, R.P. (2002). Fixed-effects negative binomial regression models. Sociological Methodology, 32(1), 247-265.

Baliga, R.B., Moyer, C.R., \& Rao, R.S. (1996). CEO duality and firm performance: What's the fuss? Strategic Management Journal, 17(1), 41-53.

Bandura, A. (2006). Toward a Psychology of Human Agency. Perspectives on Psychological Science: A Journal of the Association for Psychological Science, 1(2), 164-180.

Battle, E.S., \& Rotter, J.B. (1963). Children's feelings of personal control as related to social class and ethnic group. Journal of Personality, 31(4), 482-490.

Baum, C.F. (2001). Residual diagnostics for cross-section time series regression models. The Stata Journal, 1(1), 101-104.

Beasley, M.S. (1996). An Empirical Analysis of the Relation between the Board of Director Composition and Financial Statement Fraud. The Accounting Review, 71(4), 443-465.

Beatty, R.P., \& Zajac, E.J. (1987). CEO change and firm performance in large corporations: Succession effects and manager effects. Strategic Management Journal, 8(4), 305-317.

Belmi, P., Neale, M.A., Reiff, D., \& Ulfe, R. (2019). The social advantage of miscalibrated individuals: The relationship between social class and overconfidence and its implications for class-based inequality. Journal of Personality and Social Psychology.

Berger, P.G., Ofek, E., \& Yermack, D.L. (1997). Managerial Entrenchment and Capital Structure Decisions. The Journal of Finance, 52(4), 1411-1438. 
Bernile, G., Bhagwat, V., \& Rau, P.R. (2017). What Doesn't Kill You Will Only Make You More RiskLoving: Early-Life Disasters and CEO Behavior. The Journal of Finance, 72(1), 167-206.

Bharath, S.T., Sunder, J., \& Sunder, S.V. (2008). Accounting Quality and Debt Contracting. The Accounting Review, 83(1), 1-28.

Bourgeois, L.J. (1981). On the Measurement of Organizational Slack. Academy of Management Review, 6(1), 29-39.

Bowman, P.J., \& Howard, C. (1985). Race-related socialization, motivation, and academic achievement: A study of black youths in three-generation families. Journal of the American Academy of Child Psychiatry, 24(2), 134-141.

Boyd, B.K. (1995). CEO duality and firm performance: A contingency model. Strategic Management Journal, 16(4), 301-312.

Brockhaus, R.H. (1975). I-E locus of control scores as predictors of entrepreneurial intentions. Proceedings of the Academy of Management, 35, 433-435.

Carpenter, M. (2011). The Handbook of Research on Top Management Teams. Northampton, MA: Edward Elgar Publishing.

Chakravarthy, B.S. (1986). Measuring strategic performance. Strategic Management Journal, 7(5), 437458.

Chetty, R., Hendren, N., Lin, F., Majerovitz, J., \& Scuderi, B. 2016. Childhood Environment and Gender Gaps in Adulthood. American Economic Review, 106, 282-288.

Cronqvist, H., \& Siegel, S. (2015). The Origins of Savings Behavior. The Journal of Political Economy, 123(1), 123-169.

Cumming, D., Leung, T.Y., \& Rui, O. 2015. Gender Diversity and Securities Fraud. Academy of Management Journal, 58(5), 1572-1593.

Cyert, R.M., \& March, J.G. (1963). A behavioral theory of the firm. Englewood Cliffs, NJ: Prentice Hall.

Daily, C.M., \& Dalton, D.R. (1994). Bankruptcy and Corporate Governance: The Impact of Board Composition and Structure. Academy of Management Journal, 37(6), 1603-1617.

Daily, C.M., \& Johnson, J.L. (1997). Sources of CEO power and firm financial performance: A longitudinal assessment. Journal of Management, 23(2), 97-117.

Dechow, P.M., Hutton, A.P., \& Sloan, R.G. (2000). The relation between analysts' forecasts of long-term earnings growth and stock price performance following equity offerings. Contemporary Accounting Research, 17(1), 1-32.

Dechow, P.M., Sloan, R.G., \& Sweeney, A.P. (1996). Causes and Consequences of Earnings Manipulation: An Analysis of Firms Subject to Enforcement Actions by the SEC. Contemporary Accounting Research, 13(1), 1-36.

Deutsch, Y., Keil, T., \& Laamanen, T. (2007). Decision making in acquisitions: The effect of outside directors' compensation on acquisition patterns. Journal of Management, 33(1), 30-56.

Duckworth, K., \& Schoon, I. (2012). Beating the Odds: Exploring the Impact of Social Risk on Young People's School-to-Work Transitions during Recession in the UK. National Institute Economic Review, 222(1), 38-51.

Eisenhardt, K.M. (1989). Making Fast Strategic Decisions in High-Velocity Environments. Academy of Management Journal, 32(3), 543-576.

Fama, E., \& French, K. (1992). The cross-section of expected stock returns. Journal of Finance, 47(6), 427-464.

Fama, E.F., \& Kenneth, F.R. (1992). The cross-section of expected stock returns. The Journal of Finance, $47(2), 427-65$.

Fama, E.F., \& Kenneth, F.R. (1993). Common Risk Factors in the Returns on Stocks and Bonds. Journal of Financial Economics, 33(1), 3-56.

Findley, M.J., \& Cooper, H.M. (1983). Locus of control and academic achievement: A literature review. Journal of Personality and Social Psychology, 44(2), 419-427. 
Finkelstein, S., \& Boyd, B.K. (1998). How Much Does the CEO Matter? The Role of Managerial Discretion in the Setting of CEO Compensation. Academy of Management Journal, 41(2), 179199.

Finkelstein, S., \& D'aveni, R.A. (1994). CEO Duality as a Double-Edged Sword: How Boards of Directors Balance Entrenchment Avoidance and Unity of Command. Academy of Management Journal, 37(5), 1079-1108.

Fleiss, J.L., Levin, B., \& Paik, M.C. (2013). Statistical Methods for Rates and Proportions. Hoboken, NJ: John Wiley \& Sons.

Fredrickson, J.W., Hambrick, D.C., \& Baumrin, S. (1988). A Model of CEO Dismissal. Academy of Management Review, 13(2), 255-270.

George, G. (2005). Slack Resources and the Performance of Privately Held Firms. Academy of Management Journal, 48(4), 661-676.

Hambrick, D.C. (2007). Upper Echelons Theory: An Update. Academy of Management Review, 32(2), 334-343.

Hammond, S.A., \& Slocum, J.W. (1996). The impact of prior firm financial performance on subsequent corporate reputation. Journal of Business Ethics, 15(2), 159-165.

Harris, D., \& Helfat, C.E. (1998). CEO duality, succession, capabilities and agency theory: Commentary and research agenda. Strategic Management Journal, 19(9), 901-904.

Hausman, J.A. (1978). Specifications Tests in Econometrics. Econometrica, 46(6), 1251-71.

Hayward, M.D., Miles, T.P., Crimmins, E.M., \& Yang, Y. (2000). The Significance of Socioeconomic Status in Explaining the Racial Gap in Chronic Health Conditions. American Sociological Review, 65(6), 910-930.

Heckhausen, J., Wrosch, C., \& Schulz, R. (2019). Agency and Motivation in Adulthood and Old Age. Annual Review of Psychology, 70, 191-217.

Hill, C.W.L., \& Phan, P. (1991). CEO Tenure as a Determinant of CEO Pay. Academy of Management Journal, 34(3), 707-717.

Hölldobler, B., \&Wilson, E.O. (1977). The number of queens: An important trait in ant evolution. Naturwissenschaften, 64, 8-15.

Hoxby, C., \& Turner, S. (2013). Expanding college opportunities for high-achieving, low income students. Stanford Institute for Economic Policy Research Discussion Paper, 12-014.

Huselid, M.A., Jackson, S.E., \& Schuler, R.S. (1997). Technical and Strategic Human Resources Management Effectiveness as Determinants of Firm Performance. Academy of Management Journal, 40(1), 171-188.

Iyengar, R.J., \& Zampelli, E.M. 2009. Self-selection, endogeneity, and the relationship between CEO duality and firm performance. Strategic Management Journal, 30(10), 1092-1112.

Jackson, L.A., Sullivan, L.A., Harnish, R., \& Hodge, C.N. (1996). Achieving positive social identity: Social mobility, social creativity, and permeability of group boundaries. Journal of Personality and Social Psychology, 70(2), 241.

Judge, W.Q., \& Miller, A. (1991). Antecedents and Outcomes of Decision Speed in Different Environmental Context. Academy of Management Journal, 34(2), 449-463.

Judge, T.A., Erez, A., Bono, J.E., \& Thoresen, C.J. (2002). Are measures of self-esteem, neuroticism, locus of control, and generalized self-efficacy indicators of a common core construct? Journal of Personality and Social Psychology, 83(3), 693-710.

Kahhali, P. (2021a). Does CEO Childhood Wealth Impact Institutional Power Concentration? International Journal of Business and Public Administration, 18(1), pp. 26-40.

Kahhali, P. (2021b) Does CEO Childhood Socioeconomic Status Impact Firm Risk? International Journal of Accounting, Economics, and Finance Perspectives, 1(1).

Kahhali, P. (2022a). CEO Childhood Socioeconomic Status and Corporate Social Responsibility. American Journal of Management, 22(1), pp. 68-80. 
Kahhali, P., Aksanyar N., Maciejovsky B., Mishra, BK. (2022b). Too Much Feedback? The Effects of Relative Performance Information on Task Performance and Task Persistence. American Accounting Association Management Accounting Section Midyear Meeting.

Kahhali, P., Roman, A., \& Liu, H. (2022c). Parental Innovation Imprinting on CEO and Firm Knowledge Acquisition. In Academy of Management Proceedings (Vol. 2022, No. 1, p. 14977). Briarcliff Manor, NY 10510: Academy of Management.

Kaplan, S.N. (1994). Top Executives, Turnover, and Firm Performance in Germany. Journal of Law, Economics, \& Organization, 10, 142-59.

Kish-Gephart, J.J., \& Campbell, J.T. (2015). You don't forget your roots: The influence of CEO social class background on strategic risk taking. Academy of Management Journal, 58(6), 1614-1636.

Krause, R., \& Semadeni, M. (2013). Apprentice, departure, and demotion: An examination of the three types of CEO-board chair separation. Academy of Management Journal, 56, 805-826.

Krause, R., Semadeni, M., \& Cannella, A.A., Jr. (). CEO Duality: A Review and Research Agenda. Journal of Management, 40(1), 256-286.

MacCrimmon, K. R., \& Wehrung, D. A. 1990. Characteristics of Risk Taking Executives. Management Science, 36(4), 422-435.

Mallette, P., \& Fowler, K.L. (1992). Effects of Board Composition and Stock Ownership on the Adoption of "Poison Pills." Academy of Management Journal, 35(5), 1010-1035.

Manstead, A.S.R. (2018). The psychology of social class: How socioeconomic status impacts thought, feelings, and behavior. The British Journal of Social Psychology, 57(2), 267-291.

Martin, S.R., \& Côté, S. (2019). Social Class Transitioners: Their Cultural Abilities and Organizational Importance. Academy of Management Review, 44(3), 618-642.

Martin, S.R., Côté, S., \& Woodruff, T. (2016). Echoes of my Upbringing: How Growing Up Wealthy or Poor Relates to Narcissism, Leader Behavior, and Leader Effectiveness. Academy of Management Journal, 59(6), 2157-2177.

Miller, G.E., Chena, E., Fok, A.K., Walker, H., Lima, A., Nicholls, E.F., \& Kobor M.S. (2009). Low early-life social class leaves a biological residue manifested by decreased glucocorticoid and increased proinflammatory signaling. Proceedings of the National Academy of Sciences, 106(34), $14716-14721$.

Mohr, L.B. (1969). Determinants of innovation in organizations. The American Political Science Review, 63(1), 111-126.

Nieuwenhuis, M., Manstead, A.S.R., \& Easterbrook, M.J. (2019). Accounting for unequal access to higher education: The role of social identity factors. Group Processes \& Intergroup Relations, 22(3), 371-389.

O’Connor, J.P., Priem, R.L., Coombs, J.E., \& Gilley, K.M. (2006). Do CEO Stock Options Prevent or Promote Fraudulent Financial Reporting? Academy of Management Journal, 49(3), 483-500.

Pearce, J.A., \& Zahra, S.A. (1991). The relative power of CEOs and boards of directors: Associations with corporate performance. Strategic Management Journal, 12(2), 135-153.

Phares, E.J. (1965). Internal-external control as a determinant of amount of social influence exerted. Journal of Personality and Social Psychology, 2(5), 642-647.

Phares, E.J. (1976). Locus of control in personality. Morristown, NJ: General Learning Press.

Puffer, S.M., \& Weintrop, J.B. (1991). Corporate Performance and CEO Turnover: The Role of Performance Expectations. Administrative Science Quarterly, 36(1), 1-19.

Quigley, T.J., \& Hambrick, D.C. (2012). When the former CEO stays on as board chair: Effects on successor discretion, strategic change, and performance. Strategic Management Journal, 33(7), 834-859.

Rechner, P.L., \& Dalton, D.R. (1991). CEO duality and organizational performance: A longitudinal analysis. Strategic Management Journal, 12(2), 155-160.

Reitz, H.J., \& Jewell, L.N. (1979). Sex, locus of control, and job involvement: A six-country comparison. Academy of Management Journal, 22, 72-80. 
Rijsenbilt, A., \& Commandeur, H. (2013). Narcissus enters the courtroom: CEO narcissism and fraud. Journal of Business Ethics, 117(2), 413-429.

Rotter, J.B. (1966). Generalized expectancies for internal versus external control of reinforcement. Psychological Monographs, 80(1), 1-28.

Ryan, H.E., \& Wiggins, R.A. (2004). Who is in whose pocket? Director compensation, board independence, and barriers to effective monitoring. Journal of Financial Economics, 73(3), 497524.

Shen, W. (2003). The Dynamics of the CEO-Board Relationship: An Evolutionary Perspective. Academy of Management Review, 28, 466-476.

Shen, W., \& Cannella, A.A. (2002). Power Dynamics Within Top Management and Their Impacts on CEO Dismissal Followed by Inside Succession. Academy of Management Journal, 45(6), 1195-1206.

Singh, J.V. (1986). Performance, Slack, and Risk Taking in Organizational Decision Making. Academy of Management Journal, 29(3), 562-585.

Sundaramurthy, C., Mahoney, J.M., \& Mahoney, J.T. (1997). Board structure, antitakeover provisions, and stockholder wealth. Strategic Management Journal, 18(3), 231-245.

Thomas, A.S., Litschert, R.J., \& Ramaswamy, K. (1991). The performance impact of strategy-manager coalignment: An empirical examination. Strategic Management Journal, 12(7), 509-522.

Thompson, J.D. (1996). Organizations in action. New York: McGraw-Hill.

Tuggle, C.S., Sirmon, D.G., Reutzel, C.R., \& Bierman, L. (2010). Commanding board of director attention: Investigating how organizational performance and CEO duality affect board members' attention to monitoring. Strategic Management Journal, 31(9), 946-968.

Varaiya, N., Kerin, R.A., \& Weeks, D. (1987). The relationship between growth, profitability, and firm value. Strategic Management Journal, 8(5), 487-497.

Wiersema, M.F., \& Bantel, K.A. (1992). Top Management Team Demography and Corporate Strategic Change. Academy of Management Journal, 35(1), 91-121. 